\title{
RESEARCH
}

Open Access

\section{Remote Sensing approach to evaluate anthropogenic influences on Forest Cover of Palamau Tiger Reserve, Eastern India}

\author{
Binita Kumari, Arvind Chandra Pandey ${ }^{*}$ (i) and Amit Kumar(D)
}

\begin{abstract}
Background: Tropical forests have been experiencing remarkable rates of transformation over the past century as they are getting degraded or decimated to a great extent by anthropogenic activities. This study aims at investigating the long-term forest cover transformation in Palamau Tiger Reserve (PTR), Jharkhand, India, using Landsat TM, ETM+ ${ }^{+}$and OLI satellite images during 1975-2015. The forest cover was delineated utilizing various keys of visual interpretation techniques.

Results: The forest cover was primarily decreased in the north-eastern and north-western parts in PTR. In order to identify the anthropogenic disturbance in the forest reserve, human settlement density was mapped using highresolution Google Earth imagery. The results showed a positive correlation between human population density and settlement density. Five major affected sites with an outer buffer of $2 \mathrm{~km}$ were demarcated in order to deduce the anthropogenic influences in major non-forested sites in PTR. It was observed that the forest change was maximum at site 3 (Ranidah, area $61.06 \mathrm{~km}^{2},-6.47 \%$ change) followed by site 2 (Saidup, area $124.38 \mathrm{~km}^{2},-7.65 \%$ change), where settlement units were also high (2638 and 2621 settlement units, respectively). At site 1 (Barkheta, area 81.59 $\left.\mathrm{km}^{2}\right),-1.99 \%$ change was observed, and at site 4 (Samadh Tola, area $\left.9.15 \mathrm{~km}^{2}\right), 1.03 \%$ change was observed having moderate settlement units (2422 and 1892 settlement units, respectively). Areas with the low level of human settlements (1038 settlement units) observed the least change, i.e., at site 5 (Netarhat, area $48.52 \mathrm{~km}^{2}$ ), $0.58 \%$ change was observed mainly during the years.

Conclusions: The forest cover exhibited an overall decrease of $14.55 \mathrm{~km}^{2}(-1.34 \%$ change) with episodic variation during 1975-2015 in PTR, Eastern India. A significant forest disturbance occurred primarily in the north-eastern and north-western parts of PTR along the forest fringe due to the high population and settlement density. The study highlighted the potential use of freely available multi-temporal satellite observations in forest management.
\end{abstract}

Keywords: Population density, Settlement density, Remote sensing and GIS, Palamau Tiger Reserve

\footnotetext{
* Correspondence: arvindchandrap@yahoo.com

Department of Geoinformatics, Central University of Jharkhand, Ranchi,

Jharkhand 835205, India
} 


\section{Introduction}

The forest is a vital resource and under a high rate of change due to the combination of changing climate and anthropogenic influences (NEMA 2004). The human population increase and global change in climate were informed as crucial factors that contribute to forest cover loss and gain in seasonally dry tropical ecosystems worldwide (Lambin et al. 2003; Lepers et al. 2005). These changes contributed to the increase in agricultural expansion, the human population, and people's socioeconomic condition, and these changes activated the unsustainable removal of natural resources. Forest cover change and environmental monitoring is a significant component for natural resources management for which it is essential to generate relevant information for the management of natural assets (Lu et al. 2004).

As per an estimate, the world's total forests cover was 3.8 billion hectares in 2005 on the planet (30\% of the worldwide area of the land), in which $0.7 \%$ of forest per year was affected due to deforestation during 1990-1995 (FAO 2012). The contribution of forests to food security is often neglected, with the human population living in and around forests deriving between one fifth and one quarter of their income from forest-based sources, respectively (Wollenberg et al. 2011). The forest fringe communities depend directly or indirectly on forest products for fuelwood, food, medicines, and other nontimber forest products for their own consumption but also for commercial purpose (Megevand 2013; Banerjee and Madhurima 2013; Kumari et al. 2019). Also, the increasing human population impels the conversion of forest area primarily in the fringe due to the search of new suitable agrarian terrains (Nacoulma et al. 2012). As an outcome, forest covers are being converted into farming, pastureland, and impervious surfaces significantly affecting the biodiversity and ecosystem functioning in the region (Pereira et al. 2010; Lucas et al. 2015; Lal et al. 2017). Land cover change is exceptionally exceptional in tropical developing nations that are portrayed by farming-based economies and quickly expanding human populaces (Yeshaneh et al. 2013; Romijn et al. 2015). The anthropogenic effects on land surfaces including forests are effortlessly recognizable through temporal satellite images (Arockiaraj et al. 2015). Further, the regular monitoring of forest cover is indispensable for the preparation of forest management plans and sustainable management of forest (Franklin 2001). The dry tropical forest is debasing more expediently than the moist tropical forest, disregarding their noteworthiness for human occupants as a basis of products (Tucker et al. 2005).

Reddy et al. (2017) reported that in India, large-scale deforestation and degradation occurred in the forest dominated by dry deciduous and moist deciduous forests. This is primarily occurring due to extensive cultivation, increasing population, rapid urbanization, and rising stresses on agriculture land (Kumari and Pandey 2019). As per State of Forest Reports, India's total forest cover was 633, $397 \mathrm{~km}^{2}$ (19.27\%) in 1997 (Forest Survey of India 1997), which was insignificantly increased to $637,293 \mathrm{~km}^{2}$ (19.39\%) in 1999, 675,538 $\mathrm{km}^{2}(20.55 \%)$ in 2001, and 692, $027 \mathrm{~km}^{2}$ (21.05\%) in 2011 (FSI 1999, 2001, 2011). Later, it increased from $697,898(21.23 \%)$ to $701,673 \mathrm{~km}^{2}(21.35 \%)$ during 2013-2015 (FSI 2013, 2015). The increase in forest cover primarily occurred in the open forest (including commercial plantations) at the cost of moderately dense forest located in the proximity to human habitations (Pandey 2018). The change in the definition of forest cover as well as the use of improved satellite images in recent periods as compared to the previous forest cover estimation is also the possible reason of increased forest cover.

The Forest Survey of India in the biannual State of Forest Reports (SFR) reported the net annual loss of 99, 850 ha of forest in Jharkhand during 2007-2009 (FSI 2009, 2011). Also, due to high level of urbanization in the Ranchi district, significant rate of deforestation (0.95\%) was observed during 1996-2008 (Kumari and Pandey 2019). The forest cover in Jharkhand was 21,692 $\mathrm{km}^{2}$ in 1997 , which was decreased slightly to $22,637 \mathrm{~km}^{2}$ in 2001. However, the total forest area has been gradually increased from 22,894 to $23,478 \mathrm{~km}^{2}$ (29.45\%) during 2009-2015 (FSI 2009; FSI 2015; Fig. 1). The forest cover increase occurred mainly due to the adequate protection including plantation drive and forest protection measures by the Village Forest Protection Committees and forest department (FSI 2011).

Satellite observations at a temporal scale provide accurate information concerning deforestation and forest degradation. The development in remote sensing techniques, availability of high-resolution images in optical and non-optical region, and high temporal availability in combination with GIS has emerged as an efficient tool in continuous detection, quantification, and mapping of forest areas and its changes over the years (Sakthivel et al. 2010). To derive such information from the satellite images, visual image interpretation, digital classification, hybrid, and machine learning algorithms are the efficient techniques. Visual image interpretation technique is particularly quick, less costly, and helpful in case of limitation in technical capacities to use digital image mapping and classification (Beaubren 1986; Kushwaha et al. 2000). Human population growth results in an increase in pressures on habitats that hinder the management of the protected area considerably in forest fringe areas (Curran et al. 2004). There are very limited studies addressing the land cover change pre- and postformation of protected areas, which provide an insight of the influence of the management regimes over the 


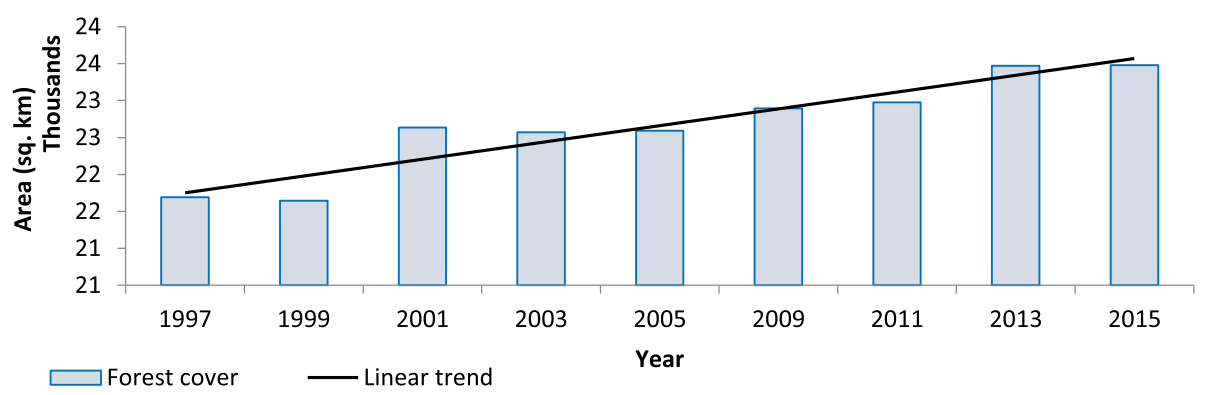

Fig. 1 Forest cover status in Jharkhand state (as per the Forest Survey of India, 1999 to 2015)

period (Sader et al. 2001). A worldwide study of 198 protected regions revealed that $\sim 70 \%$ of areas nearby buffers of protected regions had revealed deterioration in forests, though $25 \%$ of areas experienced a decrease inside the administrative boundaries (DeFries et al. 2005).

Palamau Tiger Reserve (PTR) is the first sanctuary in the world, where the census of tiger (Panthera tigris) was carried out using pugmark count in 1932 under the supervision of J.W. Nicholson. Due to forest degradation and persistent disturbances in PTR, the tiger habitat has been profoundly altered. Therefore, in the present study, the varied aspects of forest cover change were analyzed over four decades. This study aims to produce a forest cover change in PTR to identify the alterations that occurred in the region by using the change detection method from 19752015. Furthermore, the influence of anthropogenic activity on forest cover was estimated in the proximal and distant areas of the settlement units.

\section{Study area}

The forest cover of Jharkhand accounts for $29 \%$ of its total geographical area and is prone to degradation due to forest fire hazard leading to loss of green cover and biodiversity (Kumari and Pandey 2019). Palamau Tiger Reserve is situated between latitude $23^{\circ} 25^{\prime}-23^{\circ} 55^{\prime} \mathrm{N}$ and longitude $83^{\circ} 50^{\prime}-84^{\circ} 36^{\prime} \mathrm{E}$ in the Jharkhand state covering the total area of $1222.43 \mathrm{~km}^{2}$ at an elevation from 200 to $1100 \mathrm{~m}$ above sea level (ASL; Fig. 2). As per Champion and Seth (1968), the forest types of Palamau Tiger Reserve belong to moist tropical forest and dry tropical forest. The forest types of the region represented by dry deciduous forests and moist deciduous forests mainly include Sal and Bamboo.

The study area, Palamau Tiger Reserve, is well recognized as it has been endowed with rich flora and fauna. A history of drought events was seen in the Palamau region due to its geographic location in rain shadow (Rao et al. 1991). Therefore, it is declared as an economically, socially backward, and ecologically fragile zone. The state (Jharkhand) is prone to forest fires due to the dominance of dry deciduous forest that is occupied by tribal people who are dependent on the forest for their livings and are often blamed for forest fires (Banerjee and Madhurima 2013; Kumari and Pandey 2019). The tribal community is the main population of the area, and their livelihood mainly dependent on primary activities (Pandey et al. 2012; Tirkey et al. 2012). There are approximately 191 villages in PTR, which are primarily nonforest area within the reserve forest comprising settlements and agricultural land. The major settlements/villages are Morwai Kalan, Chumma, Juruhar, Wopag, Nawadih, Lat, Harhe, Bere, Hesag, Garu, Bartoli, Netarhat, and Ladi.

\section{Methodology}

In the present study, the spatial distribution of forest cover was mapped using Survey of India (SOI) topographical maps, temporal Landsat, and Sentinel 2A satellite images (Table 1). The Landsat satellite datasets were acquired from the Global Land Cover Facility (GLCF; http://glcfapp.umiacs.umd.edu:8080/esdi/index.jsp), and Sentinel 2A satellite data was acquired from earth explorer website (https://earthexplorer.usgs.gov/).

The satellite imagery from Landsat MSS (1975), TM (1991), $\mathrm{ETM}^{+}$(2001), TM (2010), and OLI (2015) was used to delineate forest and non-forest area during 1975-2015 using visual interpretation techniques and analyze forest cover change. Sentinel 2A (2015) was used to prepare the location map of the study area. Later, individual habitation units within PTR were delineated using high-resolution satellite (HRS) images from Google Earth employing visual interpretation method and used for mapping settlement density in the various zones in PTR. The population density within the different revenue villages was acquired from Census of India (2011). The settlement and population density was spatially correlated with forest cover change to deduce the anthropogenic influences in PTR. The ERDAS Imagine version-15 and Q GIS version 2.18 software were used for data preparation and geospatial analysis. 


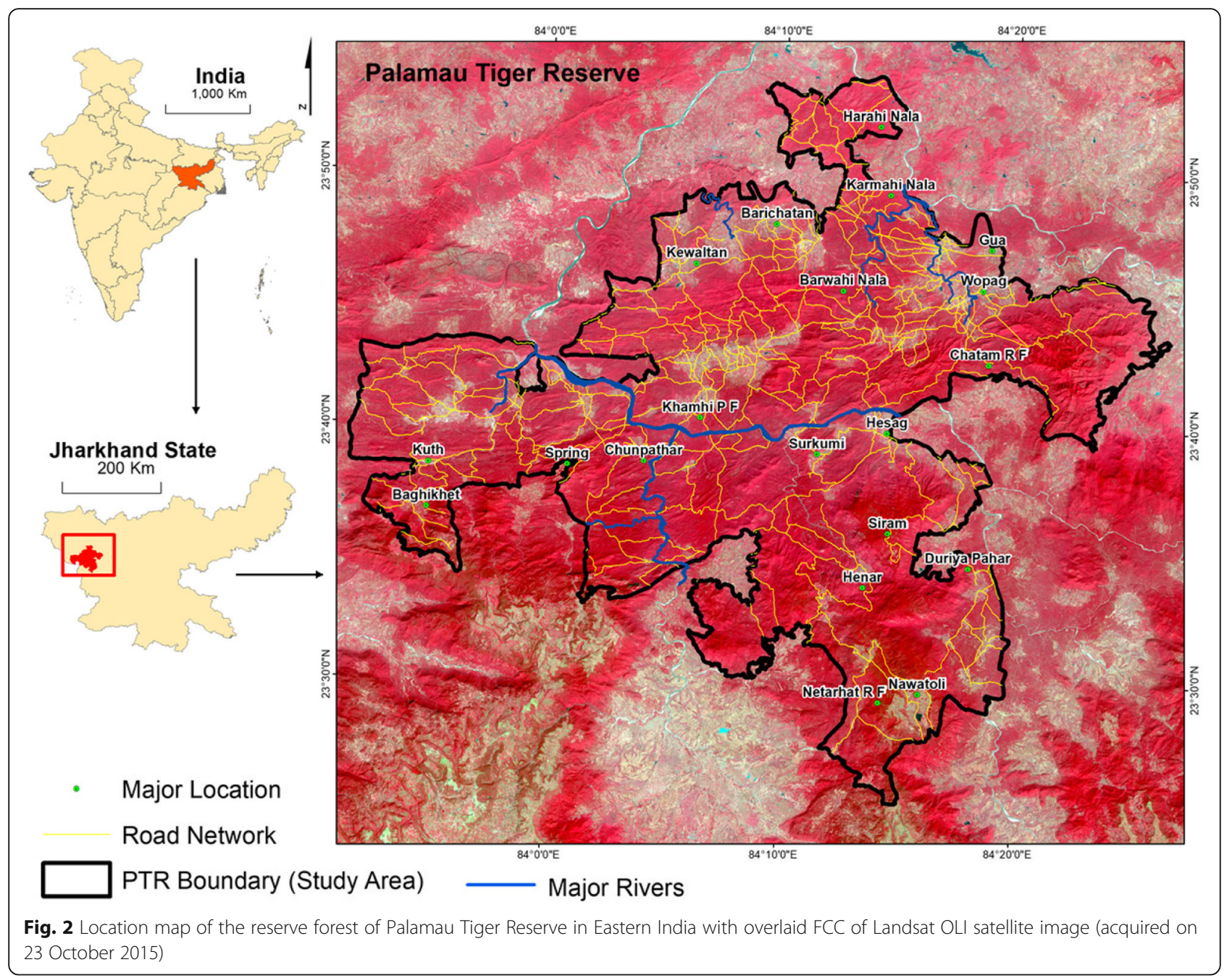

\section{Results}

\section{Spatio-temporal forest cover dynamics in PTR}

The forest and non-forest cover in Palamau Tiger Reserve were mapped using multi-temporal satellite images during 1975-2015. The satellite-based observations exhibited a gradual decrease in forest cover with the overall change of $14.55 \mathrm{~km}^{2}$ ( $-1.34 \%$ change) during 1975-2015 (Figs. 3 and 4). The periodic observations exhibit that forest cover was $1097.16 \mathrm{~km}^{2}$ (89.75\% coverage of PTR) in 1975, which slightly decreased to $1088.76 \mathrm{~km}^{2} \quad(89.07 \%$ coverage; $-0.77 \%$ change) in 1991 to $1086.69 \mathrm{~km}^{2}$ (88.90\% coverage; $0.19 \%$ change) in 2001 . It was $1086.41 \mathrm{~km}^{2}(88.87 \%$ coverage; $-0.03 \%$ change) in 2010 and $1082.61 \mathrm{~km}^{2}$ (88.56\% coverage; $-0.35 \%$ change) in 2015 (Table 2, Figs. 3 and 4). The change in forest cover was high

Table 1 Details of the data used in the study

\begin{tabular}{llll}
\hline Data type & Date of acquisition & Spatial resolution & Path-row \\
\hline Landsat 1 (MSS) & December 15, 1975 & $60 \mathrm{~m}$ & $152-44$ \\
Landsat TM & October 12, 1991 & $30 \mathrm{~m}$ & $141-44$ \\
Landsat ETM & November 22, 2001 & $30 \mathrm{~m}$ & $141-44$ \\
Landsat TM & October 21, 2010 & $30 \mathrm{~m}$ & $141-44$ \\
Landsat OLI & October 23, 2015 & $30 \mathrm{~m}$ & $141-44$ \\
Sentinel 2A & December 28, 2015 & $10 \mathrm{~m}$ & - \\
Topographical sheet no. & 1972 & $1: 250,000$ & U502 series: F44F14, F45A5, F45A2, F45A1 \\
\hline
\end{tabular}




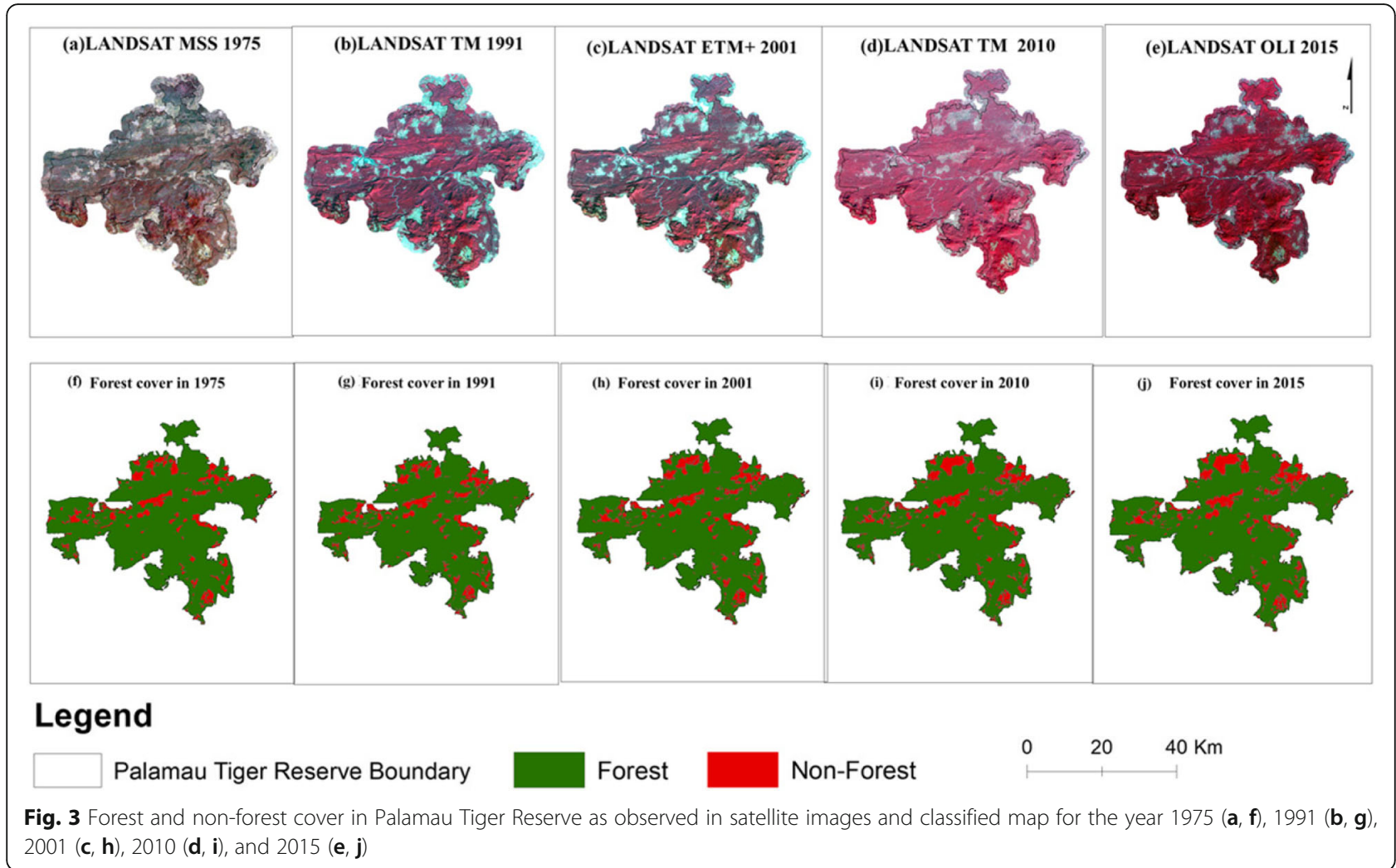

in $1991(-0.77 \%)$ and low $(-0.03 \%)$ in the year of 2010 (Table 2).

On the contrary, the satellite-based observations exhibited a gradual increase in non-forest cover, with the overall change of $14.55 \mathrm{~km}^{2}(10.40 \%$ change $)$ from 1975-2015. The non-forest cover was $125.25 \mathrm{~km}^{2}$ (10.25\% coverage) in 1975 , which slightly increased to $133.67 \mathrm{~km}^{2}\left(10.93 \%\right.$ coverage) in 1991 to $135.74 \mathrm{~km}^{2}$ (11.10\%) in 2001 to $136.02 \mathrm{~km}^{2}(11.13 \%)$ in 2010 to $139.82 \mathrm{~km}^{2}(11.44 \%)$ in 2015 (Table 2). The change in non-forest cover was high during 1975-1991 (6.71\%) and low $(-0.21 \%)$ during the period 2001-2010.

\section{Anthropogenic influence on the forests}

In order to identify the anthropogenic disturbance in reserve, human population density and settlement density was analyzed with forest cover change in PTR. The study exhibited that the central and northern parts in PTR were having a high concentration of human settlements, whereas the south-eastern and eastern parts have moderate to low concentration of human settlements (Fig. 7). It exhibits that the villages, viz, Morwai, Juruhar, Lat, Chahal, Hesag, and Netarhat, were having high settlement, whereas the villages Nawatoli, Bindag, and Totki were having the

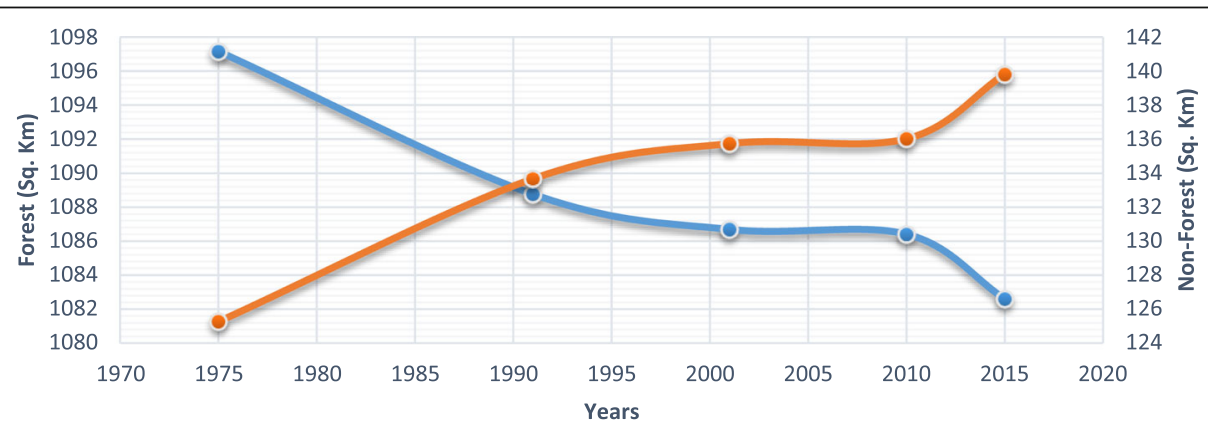

-0-Forest $=0$ Non- Forest

Fig. 4 Forest and non-forest area in PTR 
Table 2 Area statistics of forest and non-forest cover in PTR during 1975-2015

\begin{tabular}{|c|c|c|c|c|c|c|}
\hline \multirow[t]{2}{*}{ Years } & \multicolumn{2}{|c|}{ Area $\left(\mathrm{km}^{2}\right)$} & \multicolumn{2}{|c|}{ Area (\%) } & \multicolumn{2}{|c|}{ Change (\%) } \\
\hline & Forest & $\overline{\text { Non-forest }}$ & Forest & $\overline{\text { Non-forest }}$ & Forest & Non-fores \\
\hline 1975 & 1097.16 & 125.27 & 89.75 & 10.25 & - & - \\
\hline 1991 & 1088.76 & 133.67 & 89.07 & 10.93 & -0.77 & 6.71 \\
\hline 2001 & 1086.69 & 135.74 & 88.90 & 11.10 & -0.19 & 1.55 \\
\hline 2010 & 1086.41 & 136.02 & 88.87 & 11.13 & -0.03 & 0.21 \\
\hline 2015 & 1082.61 & 139.82 & 88.56 & 11.44 & -0.35 & 2.79 \\
\hline Total change & -14.55 & 14.55 & -1.19 & 1.19 & 0.42 & -3.92 \\
\hline
\end{tabular}

least concentration of population. The study indicated that the non-forest area was mainly increased in the north-east and north-west regions. In the southeastern region, a small increase in the non-forest area was observed. In the south-western region, a slight or minor increase in the non-forest area was detected. Morwai Khurd, Morwai Kalan, Pipratanr, Saletongri, Chumma, Juruhar, Sahebtikwatoli, Panhiyatola, Chakalwatoli, Nawadih, Churatoli, Luhurtola, Samadhtola, Garu, Hesag, Dhangartola, Armu, Netarhat, and Bartoli are the areas where the significant increase in non-forest cover was observed.

In the present study, the spatio-temporal forest cover change analysis of the major five sites (within PTR) was studied along with respective settlement units within the 2 -km buffer zone. The result exhibits a decrease of $1.99 \mathrm{~km}^{2}$ total vegetation cover at site 1 , vegetation loss of $-7.65 \mathrm{~km}^{2}$ at site $2,-6.47 \mathrm{~km}^{2}$ vegetation loss at site 3 , vegetation loss of $1.03 \mathrm{~km}^{2}$ at site 4 , and $0.58 \mathrm{~km}^{2}$ vegetation loss at site 5 during the period 1975-2015 (Figs. 5 and 6). The significant loss of forests may have attributed to an increase in human as well as cattle populations. The population of humans and cattle increased ten times in the eight forest villages, which has resulted in the spreading of these villages further into the core by converting forests in agriculture land and houses. The forest adjoining to these villages is gradually becoming open due to overgrazing, firewood collection, and timber collection for agriculture and household and housing activities (Department of Forest and climate change 2015).

The population density in Palamau Tiger Reserve exhibited very high (> 2000/persons) and high (1200-2000 persons) population in north-western parts and northwestern parts in PTR, respectively (Fig. 7). The area with a moderate population was observed in the southern part, whereas a low population has observed in the western parts. Morwai Kalan and Chungru villages were having the highest population. The ratio of individuals and the size of forests indicate the degree of social pressure over forest resources. The overall change (1975-2015) was observed high at site $3\left(-6.47 \mathrm{~km}^{2}\right.$ change $)$ and at site $2\left(-7.65 \mathrm{~km}^{2}\right.$ change), where settlement units were also observed high, i.e., 2638 and 2621 settlement units, respectively. Site $1\left(-1.99 \mathrm{~km}^{2}\right.$ change) and site $4(1.03$ $\mathrm{km}^{2}$ change) were observed with moderate change and were having moderate settlement units, i.e., 2422 and 1892 settlement units, respectively (Table 3 ). Areas with low human settlements (1038 units) had the least change in forest cover, i.e., $0.58 \%$.

It is worthy to note that the major alteration was evident in the northern part of PTR. Therefore, to deduce the anthropogenic influences in the forest, an outer buffer $(2 \mathrm{~km})$ of non-forest zones (site 2$)$ with a significant change in PTR was taken into consideration. The result exhibited that the significant forest cover change was observed primarily in the northern parts of PTR comprising Paisartanr, Pipratanr, Chumma, Saidup, and Barichatan villages during 1975-2015 (Figs. 7 and 8). The temporal analysis indicated that the total forest area was $101.68 \mathrm{~km}^{2}$ in the select zone in 1975 , which was reduced to $94.03 \mathrm{~km}^{2}$ in 2015 (Fig. 9). The HRS Google Earth imagery-based settlement unit mapping indicated very high settlement density (2621 housing units) in the respective area as a comparison to other non-forest zones in PTR.

\section{Discussion}

The satellite-based mapping of vegetation is effectively being performed using the visual interpretation of the acquired images (Beaubren 1986; Kushwaha et al. 2000), computer-based digital classification like supervised, unsupervised (Jensen 1986), hybrid classification, and machine learning algorithms (Hoffer 1986). The regular forest cover estimates are among the essential information required for forest management practices and preservation and restoration of plant species. The multi-temporal satellite imageries acquired from Landsat MSS (December 15, 1975), TM (October 12, 1991), ETM $^{+}$(November 22, 2001), TM (October 21, 2010), and OLI (December 28, 2015) were used to delineate forest and non-forest area boundaries during 1975 to 2015 utilizing various keys of visual interpretation techniques to assess forest cover transformation. The regular and gradual 


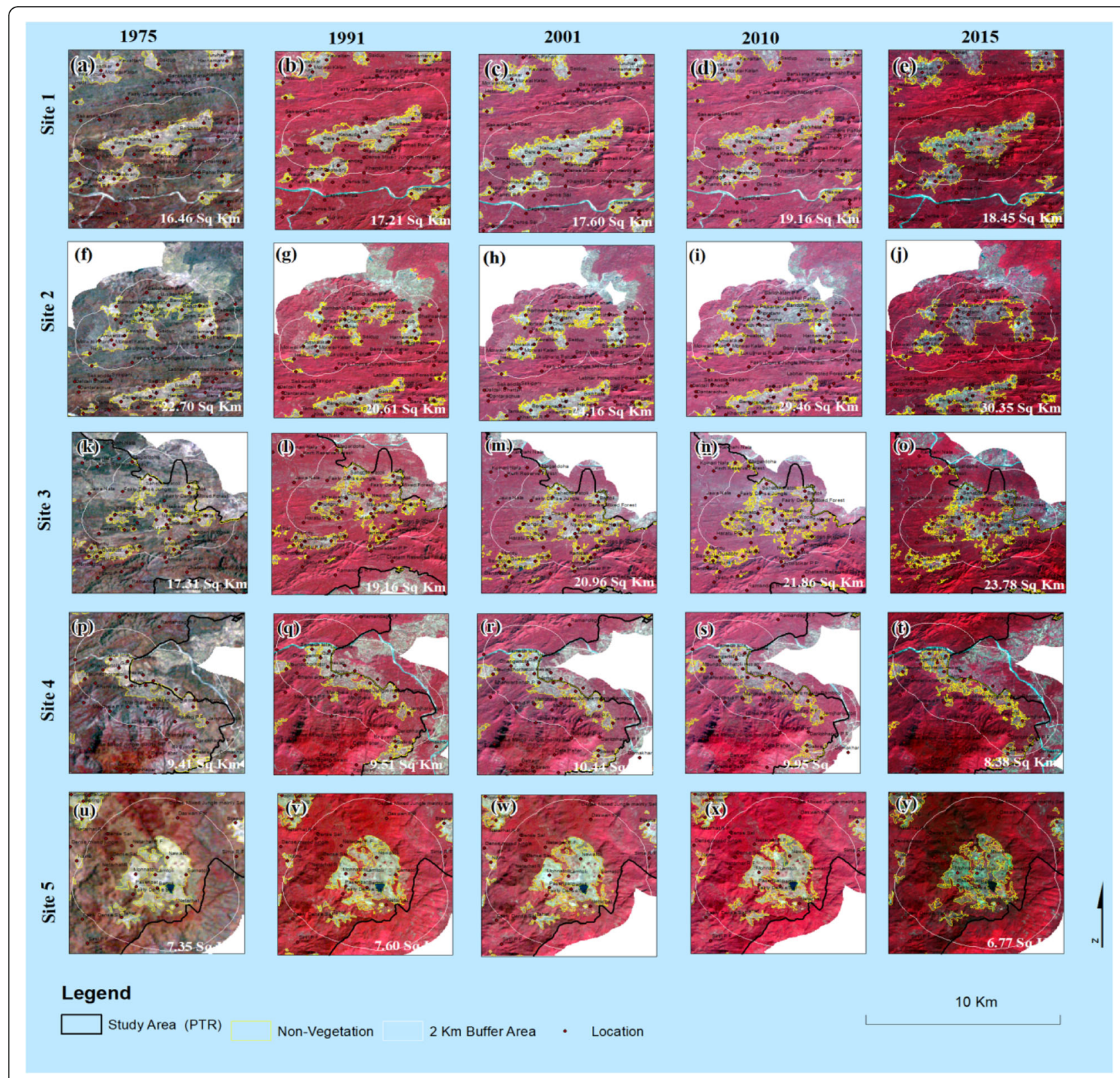

Fig. 5 a-y Periodic forest area changes in various sites within Palamau Tiger Reserve, Eastern India

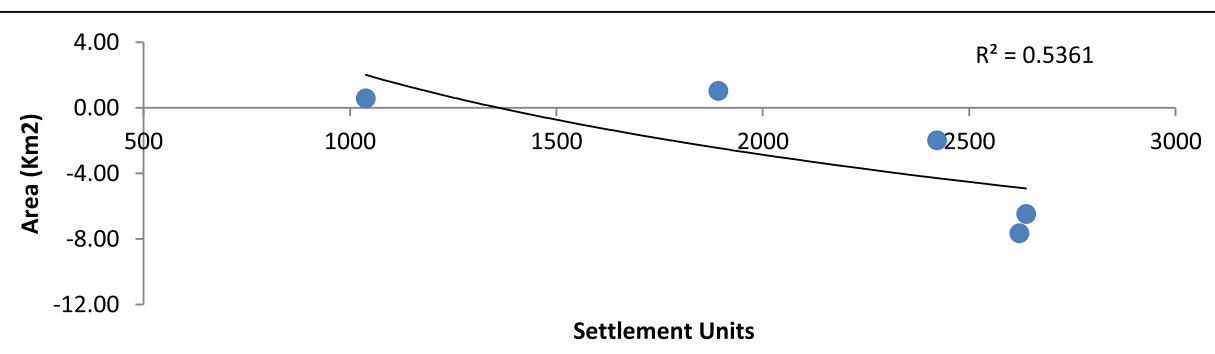

— Log. (Loss (1975-2015))

Fig. 6 Graph showing loss of forest cover during 1975-2015 


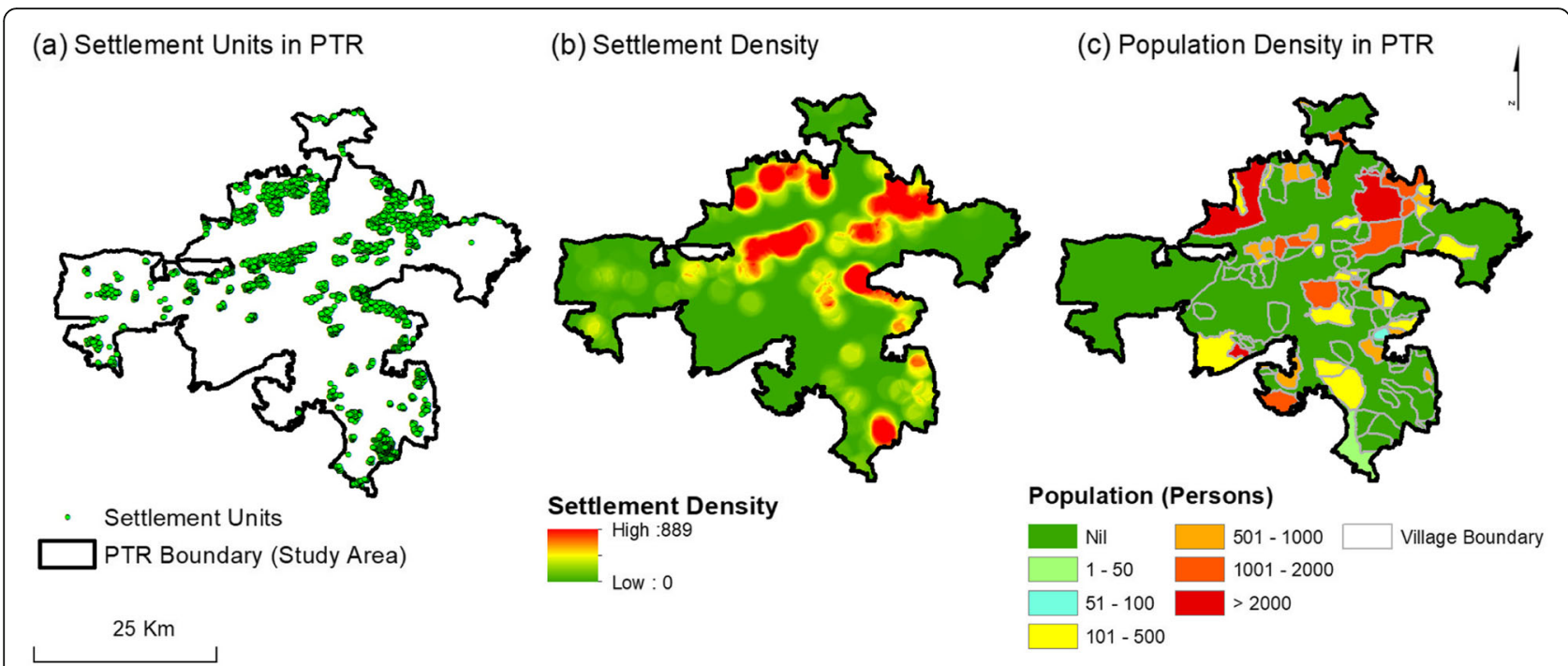

Fig. 7 a Settlement units mapped using high-resolution Google Earth imagery. b Settlement density. c Population density in Palamau Tiger Reserve

decrease in forest cover in Palamau Tiger Reserve may be attributed to the combined influence of anthropogenic as well as natural factors with varied intensity. The core area of PTR was a significant source for bamboo and timber extraction, so the area has closed for grazing and timber extraction. Cattle utilize grasslands and weeds/invasive started to appear in grasslands and in the gap area. The incidence of severe drought condition during various years also resulted in drying up of saplings, shrubs, and herbs and affects the regeneration of plant species in the forests. Frequent fire incidences in the reserve forest due to natural as well as man-made had further deteriorated habitat (Department of Forest and climate change 2015).

The human influence affects the forests differently, and the magnitude of the effects will depend sturdily on the methods employed locally, the forest type, and on other factors around and within the ecosystem. The spatiotemporal satellite monitoring revealed that significant

Table 3 Area statistics of loss of forest cover (1975-2015)

\begin{tabular}{lllllllll}
\hline $\begin{array}{l}\text { Location } \\
\text { within } \\
\text { PTR }\end{array}$ & \multicolumn{3}{l}{ Forest area $\left(\mathrm{km}^{2}\right)$} & \multicolumn{4}{c}{$\begin{array}{l}\text { Change } \\
(1975- \\
\text { 2015) } \\
(\%)\end{array}$} & $\begin{array}{l}\text { Settlement } \\
\text { units }\end{array}$ \\
\hline Site 1 & 65.13 & 64.38 & 63.99 & 62.43 & 63.14 & -1.99 & 2422 \\
Site 2 & 101.68 & 103.77 & 100.22 & 94.92 & 94.03 & -7.65 & 2621 \\
Site 3 & 85.58 & 83.73 & 81.93 & 81.03 & 79.11 & -6.47 & 2638 \\
Site 4 & 60.46 & 60.36 & 59.43 & 59.92 & 61.49 & 1.03 & 1892 \\
Site 5 & 41.17 & 40.92 & 40.91 & 41.53 & 41.75 & 0.58 & 1038 \\
\hline
\end{tabular}

forest disturbance occurred in the north-eastern and north-western parts, whereas minor forest loss has perceived in the south-western parts in PTR. The spatiotemporal change in the forest cover exhibits a significant decrease in the forest cover during 1975-2015, primarily in the vicinity of existing non-forest areas comprised of human settlements dominated by tribal population, which in combination with natural disturbances (impact of forest fire, climate change) all together influence the forest cover and habitat of the wildlife (Department of Forest and climate change 2015). The periodic monitoring using multitemporal satellite observation contributed in the effective assessment of forest and non-forest cover change and may support in the forest management plan for the protected areas of PTR.

Between 1960 and 1995, the effect of human population and economic growth on demand for food and forest products has exemplified by past consumption trends. The causes of deforestation over the 1980-1990 decade clearly show rural population growth coupled with agricultural expansion took place primarily in Africa and Asia, and economic development programs in Latin America and Asia are significant causes of changes in forest cover. The high population growth possibly caused dramatic growth in the demand for timber and non-timber products, which lead to the overexploitation of forest resources in the vicinity of forest boundary in PTR. The comparative analysis of settlement units and population concentration clearly shows a very high positive correlation between populations with the non-forest areas. Human activities such as tree cutting have altered species composition and modified forest structure to such an extent that vast 


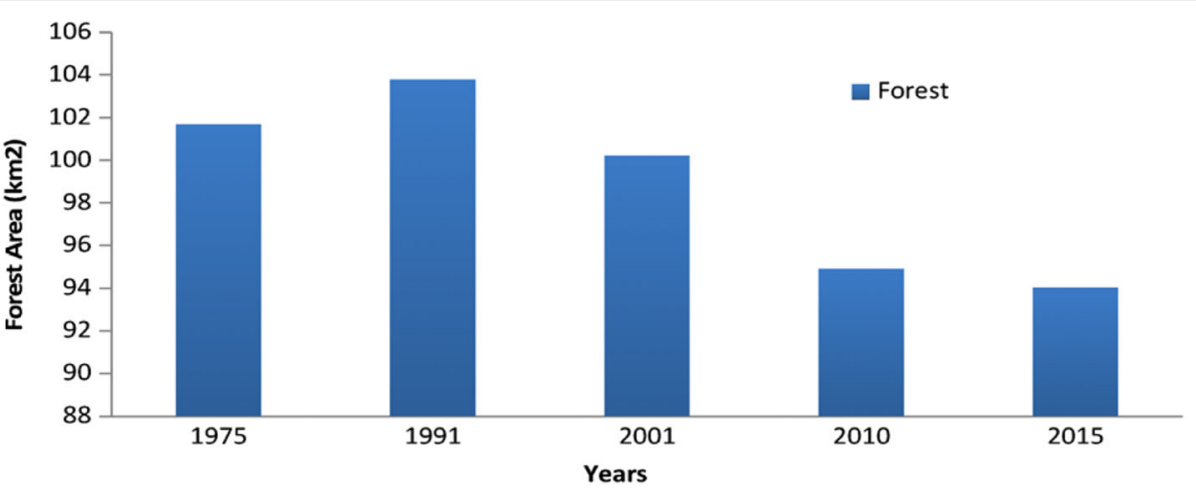

Fig. 8 Forest area of the northern parts of Palamau Tiger Reserve during 1975-2015

stretches of forest have been replaced by woodland or shrubland (Smiet 1992), and that are evident in the forest fringe area (Fig. 10). The influences of demographic changes on forests have measured in terms of forest and land-use changes, demand and ingesting of timber products, and environmental anxieties such as urban greening or forestry, recreational demand. The overall result showed that the highest loss of forest cover occurred near the area with high human population and vice versa. Agricultural expansion, logging development, and other human activities are major factors for the loss of vegetation. Although there are advantages of visual interpretation, it also has its limitations, such as it requires a skilled expert who is familiar with ground conditions. It is timeconsuming when compared to automated methods, resulting in high costs.

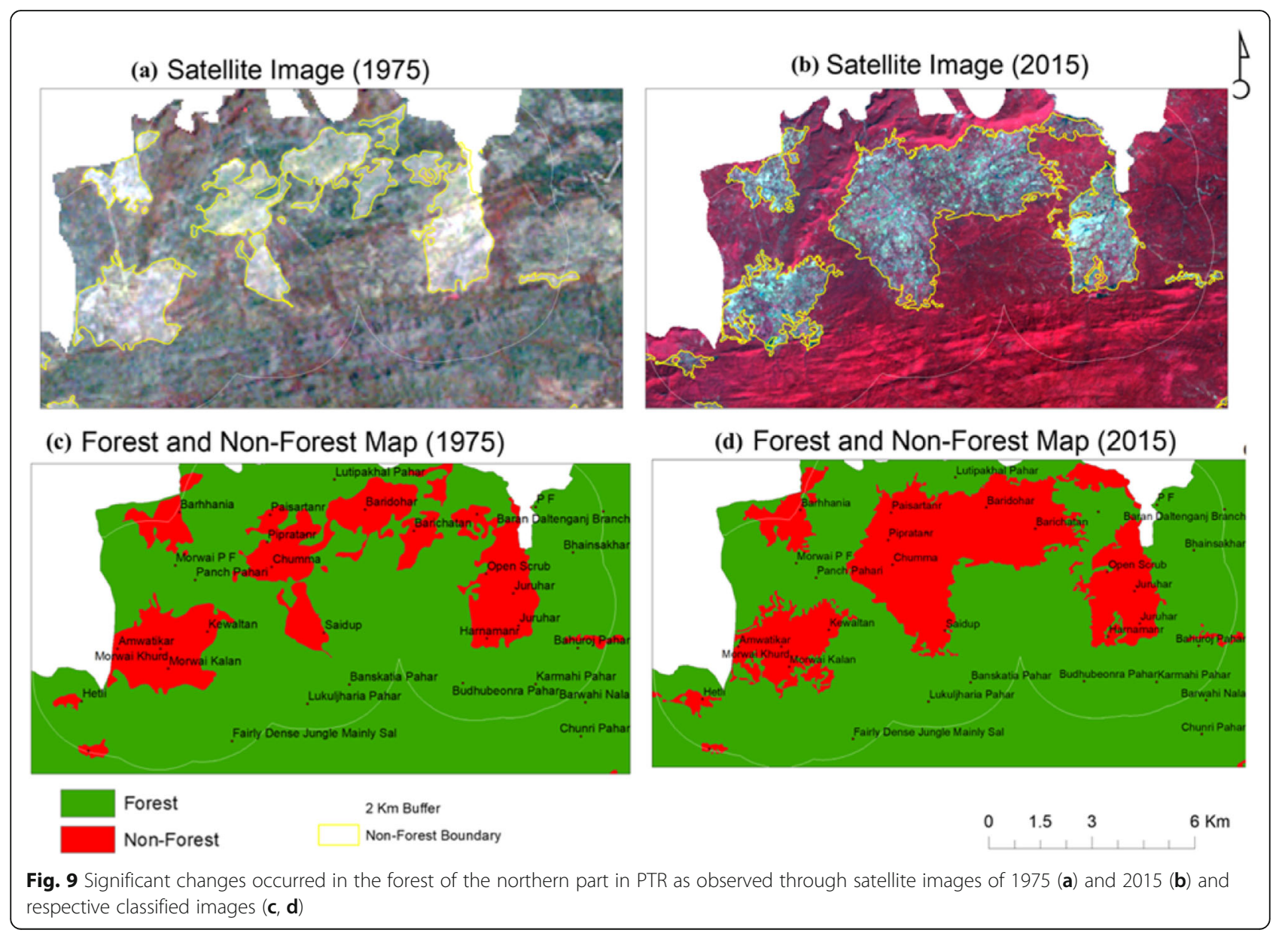



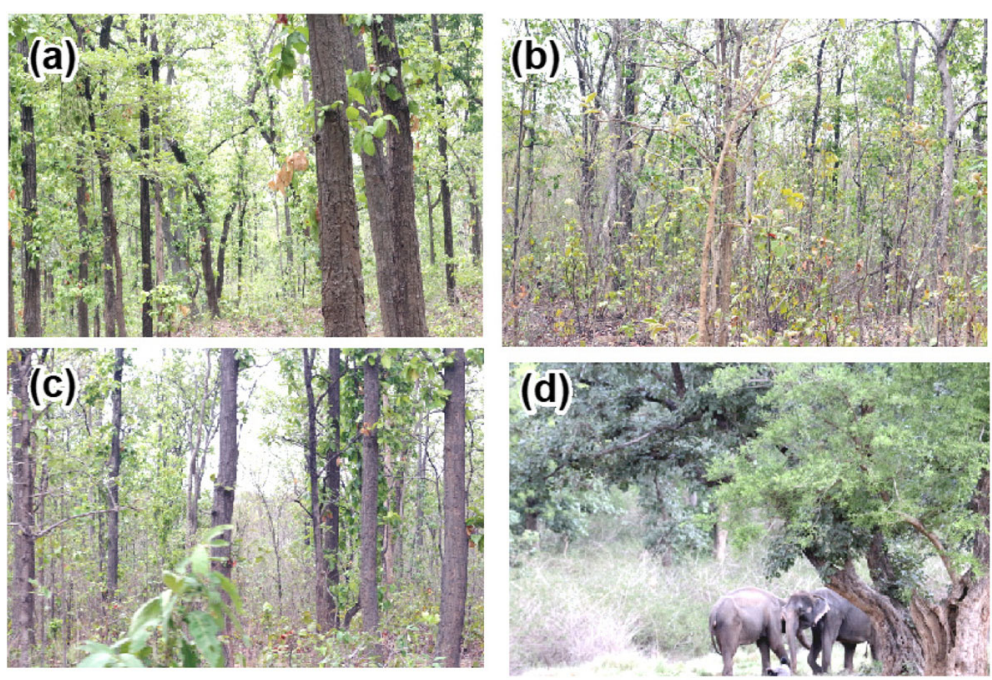

(e)

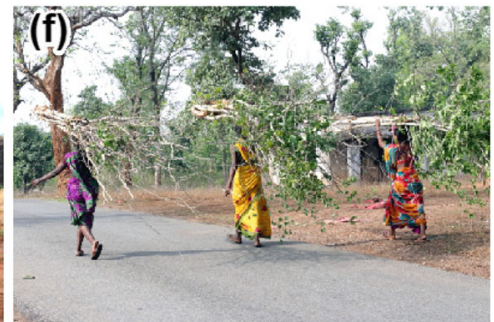

Fig. 10 Field photographs of $\mathbf{a}-\mathbf{c}$ Sal-dominated forest, $\mathbf{d}$ interaction of wild life, e forest fringe landscape, and $\mathbf{f}$ harnessing forest resources by local people in Palamau Tiger Reserve

\section{Conclusions}

The study presents the spatio-temporal forest cover change in Palamau Tiger Reserve, Eastern India, using temporal remote sensing imageries during 1975-2015 to deduce the influence of natural and anthropogenic factors in forest cover change. The study reveals a significant forest disturbance that occurred along the forest fringe in the north-eastern and north-western parts of PTR, where population increase and settlement units were higher. On the contrary, minor forest loss was observed in the south-western parts of PTR, where population increase and settlement units were comparatively lesser. The study showed good results in the satellite data-based monitoring of changes in the forest cover thereby linking them to anthropogenic factors that can utilize for effective planning and management of forest ecosystems. There was no significant forest degradation observed, which shows that the state forest departments of Jharkhand took authoritarian maintenance efforts. The increase in forest cover occurred due to plantation and protection activities. Palamau Tiger Reserve has a high grade of protection in the core zone and buffer zone after the declaration as a biosphere reserve.

\section{Abbreviations}

$\mathrm{ETM}^{+}$: Enhanced Thematic Mapper Plus; FSI: Forest Survey of India; HRS: High-resolution satellite; OLI: Operational Land Imager; PTR: Palamau Tiger Reserve; SFR: State of Forest Report; TM: Thematic Mapper

\section{Acknowledgements}

The authors are thankful to the anonymous reviewers and editors for their valuable comments, which have brought vast changes in the present manuscript. The first authors are grateful to the Central University of Jharkhand for the necessary help and financial support. The authors thank Forest Department, Jharkhand, for providing the necessary information about the study area, i.e., Palamau Tiger Reserve, Jharkhand, USGS, and Copernicus for making available the LANDSAT and Sentinel Satellite data freely, which were used in the study.

\section{Authors' Contributions}

BK wrote the initial drafts of the manuscript with comments from ACP and AK. All authors together developed the ideas and framework for the manuscript. All authors read and approved the final version of the manuscript.

\section{Funding}

Not applicable

\section{Availability of data and materials}

All data generated or analyzed during this study are included in the manuscript.

Ethics approval and consent to participate Not applicable. This is an original research. 


\section{Consent for publication}

Not applicable

\section{Competing interests}

The authors declare that they have no competing interests.

Received: 12 August 2019 Accepted: 3 February 2020

Published online: 02 April 2020

\section{References}

Arockiaraj S, Kumar A, Hoda N, Jeyaseelan AT (2015) Identification and quantification of tree species in open mixed forests using high resolution QuickBird satellite imagery. Journal of Tropical Forestry and Environment 5(2): 40-53 https://doi.org/10.31357/jtfe.v5i2.2658

Banerjee A, Madhurima C (2013) Forest degradation and livelihood of local communities in India: a human rights approach. Journal of Horticulture and Forestry 5(8):122-129

Beaubren J (1986) Visual interpretation of vegetation through digitally enhanced Landsat - MSS images. Remote Sensing Reviews 2:111-143

Champion HG, Seth SK (1968) Revised forest types of India. Government of India, New Delhi, 404

Curran LM, Trigg SN, McDonald AK, Astiani D, Hardiono YM, Siregar P, Caniago I, Kasischke E (2004) Lowland forest loss in protected areas of Indonesian Borneo. Science 303(5660):1000-1003 https://doi.org/10.1126/science.1091714

DeFries R, Hansen A, Newton AC, Hansen MC (2005) Increasing isolation of protected areas in tropical forests over the past twenty years. Ecological Applications 15(1):19-26 https://doi.org/10.1890/03-5258

Department of Forest and climate change (2015) 'Tiger Conservation Plan'. Government of Jharkhand

FAO (2012) State of the world's forests. Food and Agriculture Organisation of the United Nations, Rome

Franklin SE (2001) Remote sensing for sustainable forest management. CRC Press, London

FSI (2009) India State of Forest Reports, Forest Survey of India, Dehradun. MoEF, Gol FSI (2011) India State of Forest Reports, Forest Survey of India, Dehradun. MoEF, Gol

FSI (2013) India State of Forest Reports, Forest Survey of India, Dehradun. MoEF, Gol

FSI (2015) India State of Forest Reports, Forest Survey of India, Dehradun. MoEF, Gol

Hoffer RM (1986) Digital analysis techniques for forestry applications. Remote Sensing Reviews 2:61-110

Jensen JR (1986) Introductory digital image processing - a remote sensing perspective. Prentice Hall, New York, USA

Kumari B and Pandey AC (2019) MODIS based forest fire hotspot analysis and its relationship with climatic variables. Spatial Information Research https://doi. org/10.1007/s41324-019-00275-z

Kumari R, Banerjee A, Kumar R, Kumar A, Saikia P, Khan ML (2019) Deforestation in India: consequences and sustainable solutions. In: Deforestation around the world. Mohd Nazip Suratman and Dr. Zulkiflee Abd Latif (Eds.) IntechOpen Publisher, London

Kushwaha SPS, Rocky P, Leima S, Roy PS (2000) Plantation type differentiation from fused IRS data - an analysis. Proceeding of the Spatial Technologies for Natural Hazards Management. Indian Institute of Technology, Kanpur, 21-22 November, 2000, 233-238

Lal K, Kumar D, Kumar A (2017) Spatio-temporal landscape modeling of urban growth patterns in Dhanbad Urban Agglomeration, India using geoinformatics techniques. Egyptian Journal of Remote Sensing and Space Science 20(1):91-102 https://doi.org/10.1016/j.ejrs.2017.01.003

Lambin EF, Helmut JG, Lepers E (2003) Dynamics of land-use and land-cover change in tropical regions. Annual Review of Environment and Resources 28(1): 205-241. https://doi.org/10.1146/annurev.energy.28.050302.105459 .

Lepers E, Lambin EF, Janetos AC, Defries R, Achard F, Ramankutty N, Scholes RJ (2005) A synthesis of information on rapid land-cover change for the period 1981-2000. BioScience 55(2):115-124. https://doi.org/10.1641/0006-3568 (2005)055[0115:asoior]2.0.co;2

Lu D, Mausel P, Brondízio E, Moran E (2004) Change detection techniques. International Journal of Remote Sensing 25(12):2365-2407 https://doi.org/10. 1080/0143116031000139863

Lucas R, Blonda P, Bunting P, Jones G, Inglada J, Arias M, Mairota P (2015) The earth observation data for habitat monitoring (EODHaM) system. International Journal of Applied Earth Observation and Geoinformation 37:1728 https://doi.org/10.1016/j.jag.2014.10.011
Megevand C (2013) Dynamiques de Déforestation Dans Le Bassin Du Congo. International Bank for Reconstruction and Development / The World Bank.

Nacoulma BMI, Schumann K, Traoré S, Bernhardt-Römermann M, Hahn K, Wittig R, Thiombiano A (2012) Impacts of land-use on West African savanna vegetation: a comparison between protected and communal area in Burkina Faso. Biodiversity and Conservation 20:3341-3362

NEMA (2004) State of Environment Report for Uganda 2004/05. Environment:1-301

Pandey K (2018) Why increase in global tree cover does not call for celebration. Down to Earth. https://www.downtoearth.org.in/news/forests/why-increasein-global-tree-cover-does-not-call-for-celebration-61588

Pandey S, Pandey AC, Nathawat MS, Kumar M, Mahanti NC (2012) Drought hazard assessment using geoinformatics over parts of Chotanagpur Plateau Region, Jharkhand, India. Natural Hazards 63(2):279-303 https://doi.org/10. 1007/s11069-012-0093-9

Pereira HM, Leadley PW, Proença V, Alkemade R, Scharlemann JPW, FernandezManjarrés JF, Araújo MB (2010) Scenarios for global biodiversity in the 21st century. Science 330(6010):1496-1501 https://doi.org/10.1126/science.1196624

Rao PD, Behera G, Navalgund RR, Karale RL, Rao RS (1991) IRS-1A application for district level planning. Current Science 61:3-4

Reddy CS, Jha CS, Manaswini G, Alekhya WLP, Pasha SV, Satish KV, Diwakar PG, Dadhwal VK (2017) Nationwide assessment of forest burnt area in India using Resourcesat-2 AWiFS data. Current Science 112:1521-1532

Romijn E, Lantican C, Herold M, Lindquist E (2015) Assessing change in national forest monitoring capacities of 99 tropical countries. Forest Ecology and Management 352:109-123

Sader SA, Hayes DJ, Hepinstall JA, Coan M, Soza C (2001) Forest change monitoring of a remote biosphere reserve. International Journal of Remote Sensing 22(10):1937-1950 https://doi.org/10.1080/01431160117141

Sakthivel R, Manivel M, Raj NJ, Pugalanthi V, Ravichandran N, Anand VD (2010) Remote sensing and GIS based forest cover change detection study in Kalrayan Hills, Tamil Nadu. Journal of Environmental Biology 31(5 SUPPL):737-747

Smiet AC (1992) Forest ecology on java: human impact and vegetation of montane forest. Journal of Tropical Ecology 8(5):129-135

Tirkey AS, Pandey AC, Nathawat M (2012) Groundwater level and rainfall variability trend analysis using GIS in parts of Jharkhand state (India) for sustainable management of water resources. International Research Journal of Environmental Sciences 1(4):24-31

Tucker CM, Munroe DK, Nagendra H, Southworth J, Tucker C (2005) Comparative spatial analyses of forest conservation and change in Honduras and Guatemala. Conservation and Society 3(1):174-200

Wollenberg E, Campbell BM, Holmgren P, Seymour F, Sibanda L, Braun J (2011) Actions needed to halt deforestation and promote climate-smart agriculture. CCAFS Policy Brief 4. Climate Change Agriculture and Food Security CCAFS. Copenhague, Danemark

Yeshaneh E, Wagner W, Exner-Kittridge M, Legesse D, Blöschl G (2013) Identifying land use/cover dynamics in the Koga catchment, Ethiopia, from multi-scale data, and implications for environmental change. ISPRS International Journal of Geo-Information 2:302-323 https://doi.org/10.3390/ijgi2020302

\section{Publisher's Note}

Springer Nature remains neutral with regard to jurisdictional claims in published maps and institutional affiliations.

\section{Submit your manuscript to a SpringerOpen ${ }^{\circ}$ journal and benefit from:}

- Convenient online submission

- Rigorous peer review

- Open access: articles freely available online

- High visibility within the field

- Retaining the copyright to your article

Submit your next manuscript at $\boldsymbol{\sim}$ springeropen.com 